\title{
PARAMETRICAL ANALYSIS OF THE COMMERCIAL NAME
}

\section{Syniavska Olga ${ }^{1}$}

DOI: http://dx.doi.org/10.30525/978-9934-571-27-5_47

Abstract. The efficiency of commercial names is defined by both linguistic, and extralinguistic criteria. The last can be realized by means of the parametrical analysis of a name. This work is devoted to the description of this process and application of techniques of this analysis in practice. The purpose of the paper is to study and describe modern Russian names in aspect of experimental data. Object of research are modern Russian names of drinks and confectionery. Experimental base of a research were results of poll in total of 60 respondents. The main method of a research used in work is descriptive along with which the parametrical techniques used for an experiment were also applied: method of subjective definitions, method of definition of subjective expectations, method of identification of visions, method of definition of subjective preferences, method of the phonosemantic analysis, method of determination of esthetic appeal. The efficiency of commercial names is defined by both linguistic, and extralinguistic criteria. The linguistic analysis of names from the point of view of their compliance to criteria of the ideal name has brought the following results. The phonologic criterion is answered by such names, which have the following signs: harmony and ease of pronunciation; absence of undesirable phonetic associations; lack of a floating accent. From the point of view of lexical and semantic criterions, those commercial names, which find unconditional communication with called are successful and can adequately reflect the hypo-hyperonym relations in group of names. The semantic criterion assumes unambiguity of perception of the name. The quality of set of the interconnected criteria of an adequate name and its efficiency can be revealed by means of the parametrical analysis. The parametrical analysis of the name is the method of a research assuming the description of the commercial nomination in a number of previously selected parameters. The purpose of the parametrical analysis - experimentally to confirm adequacy of theoretical criteria of the ideal name in practice. By means of the made

${ }^{1} \mathrm{PhD}$, Senior Lecturer at Department of Russian Language and Literature, Kyiv National Linguistic University, Ukraine 
experiment the attempt to prove adequacy of the offered linguistic criteria of the ideal commercial name by means of the parametrical analysis has been made.

\section{Introduction}

Active development of the commercial nomination in modern society, causes the need for the description of process of formation of names, studying of results of researches for this sphere, definition and development of recommendations about creation of the effective commercial nomination. The efficiency of commercial names is defined by both linguistic, and extralinguistic criteria. The last can be realized by means of the parametrical analysis of a name. This work is devoted to the description of this process and application of techniques of this analysis in practice.

The purpose of the paper is studying and the description of modern Russian names in aspect of experimental data.

For achievement of a goal the following tasks have been set:

- to define the main linguistic criteria of the modern commercial name;

- to analyse compliance of theoretical linguistic criteria of creation of the adequate name by means of an experiment.

Object of research are modern Russian names of drinks and confectionery.

Research material - commercial names alcoholic (vodka, wine), low alcohol (cocktail, beer), soft drinks (kvass, tea, milk) and confectionery. The research was conducted on the basis of the Russian names of goods.

Experimental base of a research were results of poll in total of 60 respondents.

The main method of a research used in work is descriptive along with which the parametrical techniques used for an experiment were also applied:

- method of subjective definitions;

- method of definition of subjective expectations;

- method of identification of visions;

- method of definition of subjective preferences;

- method of the phonosemantic analysis;

- method of determination of esthetic appeal of the name.

During creation of the successful name it is necessary to take target audience for which the goods are designed into account. To learn preferences of buyers, it is necessary to put previously psycholinguistic experiments and to conduct survey of consumers. For example, associative experiment; an 
experiment by an addition technique; scaling; method of semantic differential, method of semantic integral, and some other.

The main directions in the sphere of the commercial nomination is the following: development of criteria of creation of an effective and adequate name [2, p. 23-25]; technique of a name [1, p. 79-119]; formation of the modern register of models of a name; the analysis and elimination of wrong decisions in the sphere of the commercial nomination; creation of complementary semiotics networks of a name in the conditions of multimedia communication; providing mechanisms of renaming and some other [4].

Interest in commercial names steadily grows. In the market appears more and more companies needing services of a naming. Also the number of the organizations offering professional development of commercial names increases. All this creates favorable circumstances for researches in the field of the commercial nominations.

The efficiency of the nomination is defined by the semantic potential put in the corresponding name representing set of the interconnected signs perceived by language consciousness as a complete image [1, p. 5]. The specified signs and their ratio can be revealed by means of the parametrical analysis.

Results of the parametrical analysis of the commercial nomination are illustrated on the example of group of previously selected names of drinks and confectionery. They are the following: «36 копеек» (milk), "Анастасия» (wine), «Бельй пакет» (juice), «Гладиатор» (beer), «Госпожа Удача» (vodka), «Гостинчик» (candies), «Грех кардинала» (vodka), «Кузьмич» (vodka), «Лампочка» (vodka), «Морелия» (candies), «Наливай-ка» (vodka), «Паго» (juice), «Привет» (juice), «Родник королевы-лягушки» (wine), «Розовый зайчик» (cocktail), «Самоивет» (tea), «Фазер» (candies), «Ходзитя» (wine), «Черновар» (beer), «Ярило» (kvass). All cited words belong to names of drinks and confectionery.

These names - the words and phrases classified by various signs:

- internal form of a word: «Анастасия» (wine), «Кузьмич» (vodka), «Родник королевы-лягушки» (wine), «Розовый зайчик» (cocktail);

- morphological derivation: «Самоивет» (tea), «Наливай-ка» (vodka), «Гостинчик» (candies), «Черновар» (beer);

- origin of a word (primordial / loan words): «Привет» (juice), «Лампочка» (vodka), «Ходзитя» (wine), «Фазер» (candies); 
- lexico-semantic category of words (abstract / concrete words): «Госпожа Удача» (vodka), «Грех кардинала» (vodka), «36 копеек» (milk), «Бельй пакет» (juice);

- emergence on the historical arena (neologisms / obsolete words): «Морелия» (candies), «Паго» (juice), «Ярило» (kvass), «Гладиатор» (beer).

\section{Linguistic analysis}

The linguistic analysis of these names of confectionery and drinks from the point of view of their compliance to criteria of the ideal name has brought the following results.

The phonologic criterion is answered by such names, which have the following signs: harmony and ease of pronunciation; absence of undesirable phonetic associations; lack of a floating accent.

Names meet these requirements: «Анастасия» (wine), «Кузьмич» (vodka), «Самоивет» (tea), «Наливай-ка» (vodka), «Гостинчик» (candies), «Черновар» (beer), «Привет» (juice), «Лампочка» (vodka), «Фазер» (candies), «Ярило» (kvass), «Гладиатор» (beer). They are easily said, are laconic and have no floating accent. The names «Ходзитя» (candies) and «Паго» (juice) aren't harmonious and are difficult for reading and pronunciation therefore they are unsuccessful for a description of goods.

The principle of laconicism is broken by the names representing phrases. But among them there are those which are rather well memorable due to the figurativeness: «Родник королевы-лягушки» (wine), «Розовый зайчик» (cocktail), «Госпожа Удача» (vodka), «Грех кардинала» (vodka).

The names «36 копеек» (milk) and «Бельий пакет» (juice) not only consist of two words, but also don't cause special images and associations and therefore aren't rather successful for the use as the name.

From the point of view of lexical and semantic criterion, those names, which find unconditional communication with called are successful and can adequately reflect the hypo-hyperonym relations in group of names [3, p. 400]. This criterion is answered by the following names: «Самоивет» (tea), «Наливай-ка» (vodka), «Гостинчик» (candies).

For names of drinks personal names are often used, therefore the nomination «Анастасия» for the name of wine can be considered as successful. Colloquial words are also characteristic of names of alcoholic beverages of the mass use. They create the atmosphere of proximity, likeness, 
warm-heartedness. Therefore, the use of the name «Кузьмич» for designation of vodka is rather successful.

The name of wine «Родник королевы-лягушки», juice «Привет», vodka «Лампочка», milk «36 копеек» don't reflect real communication with goods, and, therefore, aren't successful for use as the name of goods.

Use of loans which are little-known to the mass consumer and the neologisms which don't have denotativny correlation to real goods as the name doesn't promote his adequate perception. Therefore, use of the names «Черновар» (beer), «Ходзитя» (wine), «Фазер» (candies), «Морелия» (candies), «Паго» (juice) isn't motivated.

The semantic criterion assumes unambiguity of perception of the name. Unsuccessful in this plan the names "36 копеек» (association with low cost of goods, therefore, and bad quality), «Грех кардинала» (association with crime), «Морелия» (associations with the morbidity, death), «Родник королевы-лягушки» (association with the swamp, untidiness), "Черновар» (association with black liquid).

If the names having double meaning, but not containing at the same time negative sense are perceived positively: "Гладиатор» (beer and fighter in Ancient Rome), "Госпожа Удача» (vodka and popular song), «Гостинчик» (candies and gift, as a rule, in the form of tasty delicacies), «Привет» (juice and greeting), «Розовый зайчик» (cocktail and soft toy), «Самоивет» (tea and gemstone).

Thus, from the point of view of linguistic requirements to the name as successful it is necessary to recognize names «Анастасия» (wine), «Гладиатор» (beer), «Госпожа Удача» (vodka), «Гостинчик» (candies), «Кузьмич» (vodka), «Наливай-ка» (vodka), «Розовый зайчик» (cocktail), «Самоивет» (tea), «Ярило» (kvass). They correspond to a number of linguistic criteria which have been put forward as defining for the ideal name. Other names («36 копеек» (milk), «Бельй пакет» (juice), «Грех кардинала» (vodka), «Лампочка» (vodka), «Морелия» (candies), «Паго» (juice), «Привет» (juice), «Родник королевы-лягушки» (wine), «Фазер» (candies), «Ходзитя» (wine), «Черновар» (beer)) aren't suitable as the name of goods on a number of characteristics.

The ideal modern commercial name combines set of linguistic criteria as the adequate name has to be not only unique, but also have a successful sound row, it is easy to be said, reflect communication with real goods, not to cause negative emotions and associations. Only on condition of inte- 
grated system approach the name, the most corresponding to the set criteria can be developed.

\section{Parametrical analysis}

The parametrical analysis of the name is the method of a research assuming the description of the commercial nomination in a number of previously selected parameters.

The parametrical analysis assumes use of the following techniques: method of subjective definitions, method of definition of subjective expectations, method of identification of visions, method of definition of subjective preferences, method of the phonosemantic analysis, method of determination of esthetic appeal [1, p. 20].

Perception and assessment of the commercial name by the native speaker is carried out in a complete image. Use of the parametrical analysis will allow to explain a phenomenon of efficiency / inefficiency of the name, to formulate linguistic and extralinguistic requirements of the effective nomination on the basis of determination of quantitative meanings of her indicators, to experimentally confirm adequacy of theoretical criteria of an ideal name in practice.

Thus, for definition of the ideal name has been led the method of the parametrical analysis of the name. The purpose of the parametrical analysis - experimentally to confirm adequacy of theoretical criteria of the ideal name in practice.

As examinees 60 people aged from 15 up to 55 years have been chosen. Survey was conducted in an individual form. Informants were offered to answer a number of previously prepared questions by means of which names were estimated from the point of view of their compliance to criteria of the ideal name.

\subsection{Method of identification of subjective definitions}

By means of a method of identification of subjective definitions it is possible to reveal one complete definition of the offered name.

Examinees were offered to answer a question in writing: "What, in your opinion, means this name?".

Poll was carried out in an individual form. The received results are presented below in the following form: the defined word; number of respondents; words definitions in decreasing order of their rate (equifrequent reac- 
tions are given in alphabetical order); the number of refusals (that is number of the informants which haven't pledged a definition this word).

It should be noted that the request difficulties caused to give a definition in some cases at examinees. In certain cases it led to refusals in answers (the maximum number of refusals when determining the words «Грех кардинала», «Морелия», "Паго», "Родник королевы-лягушки», «Фазер», «Ходзитя»), in some it has led to emergence of words associations, but not real definitions, for example, the answer Мария Медичи in relation to the words «Грех кардинала».

Cases of a false definition are found, for example, «Морелия»-ancient goddess of death; "Паго»-parrot; «Ходзитя» - Belarusian, state institution, Japanese. It demonstrates that the names having indistinct correlation to real goods («Грех кардинала», «Родник королевь-лягушки»), also as well as neologisms («Морелия», «Паго») and loanwords («Фазер», «Ходзитя») aren't successful as a description of goods.

Attempts to give definition of a word through concrete examples met (dog, grandfather, man, drunkard in relation to the word «Kyзьмич»). Some part of definitions had estimated character, for example: «36 копеек»-something cheap; «Гладиатор» - strong person; «Грех кардинала»-something forbidden; «Кузьмич» - something rural; «Черновар»-bad person.

Some features of the called subject were in some cases specified («Гладиатор» - person battling against a tiger or a lion; «Морелия»something from sea; «Фазер»-foreign word; «Ходзитя»-Chinese word).

These observations confirm that very important for the name is figurativeness, ability to cause certain associations in the consumer. In one cases they have positive character («Гладиатор» - strong person), in others negative («36 копеек» - something cheap; «Грех кардинала»-something forbidden; «Кузьмич» - something rural; «Черновар»-bad person). Big role belongs also to associations of personal character (for example, «Кузьмич»-drunkard, dog).

A certain share of the definitions offered by examinees correlates with character of the offered goods, for example: «36 копеек», "Анастасия», «Бельй пакет», «Гладиатор», «Госпожа Удача», «Гостинчик», «Кузьмич», «Лампочка», «Наливай-ка», «Розовый зайчик», «Самоцвет», «Ярило»- more than $30 \%$ of adequate definitions. All these words, behind an exception «Наливай-ка», are primordial and common in informal conversation. The name «Наливай-ка» was defined adequately 
thanks to the pronounced internal form which helps to find a real word meaning.

By means of a method of definition of subjective definitions it was succeeded to establish that the names «Грех кардинала» (vodka), «Морелия» (candies), «Паго» (juice), «Родник королевь-лягуики» (wine), «Фазер» (candies), «Ходзитя» (wine), "Черновар» (beer) are unsuccessful as examinees had problems with their definition. It is connected with the fact that some of these words, breaking phonetic criterion, are insufficiently harmonious and are hard said ((«Паго» (juice), «Ходзитя» (wine)).

Neologisms («Морелия» (candies), «Паго» (juice), «Черновар» (beer)) and loanwords («Фазер» (candies), «Ходзитя» (wine)) don't conform to the lexical requirement. They aren't adapted to a daily lexicon of consumers and are difficult perceived by them. The names «Грех кардинала» (vodka) and «Родник королевы-лягушки» (wine) are unsuccessful as names of goods as have negative figurativeness and cause negative associations.

\subsection{Method of definition of subjective expectations}

The method of definition of subjective expectations allows reveals degree of sensibleness of the consumer who is guided by the name at the choice of goods.

Survey was conducted according to the scheme described above. The examinee was offered to answer a question: «How you think what goods have this name?».

When performing this task the largest number of refusals met in relation to the words «Паго» (more than 30\%), «Фазер» (more than 25\%) and «Ходзитя» (more than 30\%). This fact confirms that it is rather heavy for consumers to identify loanwords and neologisms.

In some cases examinees specified not goods, but character of an object with the offered name, for example, «Анастасия» - clothing store; «Бельіи nакет»-supermarket; «Гладиатор»-weapon shop.

Cases of exact perception of a word name are noted: «Ярило»$66 \%$ of adequate answers; «Наливай-ка»-60\%; «Гостинчик» - 53\%, «Кузьмич» $-40 \%$. It demonstrates to successful use of these words as names of goods as their internal form transfers a direct connection of the name with real goods.

Results of the experiment made by means of a method of definition of subjective expectations confirm a thought that use as commercial names of 
words semantic unfamiliar to the native speaker isn't justified. For example, most of examinees consider that under the name «Морелия» (candies) seafood is on sale, «Фазер» (candies) - household appliances, «Ходзитя» (wine) - sushi.

\subsection{Method of identification of visions}

The method of identification of visions gives the chance to find the visions arising at the consumer in connection with the offered name.

Examinees have received a task: «Describe the vision caused by the name of these goods».

It should be noted that visions are more individual and various, than subjective expectations and subjective definitions. For example, «Анастасия»tall, slender, long-haired girl, little girl, the heroine of series «Poor Nastya», reflection in a mirror, Teslenko Nastya; "Гладuamop»-Russell Crowe, strong high brunette, Valuyev; «Госпожа Удача»-frames from the movie "White Sun of the Desert», man with a guitar, grandmother, cheerful woman, blue-eyed blonde, lady in a dress, bright poster; "Кузьмич»-actor from the movie «Features of National Fishing», mechanic, cat, dog, neighbor, spaniel, tractor operator.

As a result of this poll a number of names has caused refusal in the answer. These are such names as «Грех кардинала» (more than 30\% of refusals), «Морелия» (20\%), «Паго» (40\%), «Фазер» (33\%), «Ходзитя» (33\%), «Черновар» (26\%). These words haven't caused visions in consciousness of examinees because they are semantic unfamiliar to native speakers.

So, the name «Грех кардинала» has caused difficulties because of a variety of reasons. First, the difficulty consists that a noun sin abstractly to describe him rather difficult. Secondly, the few from informants have a clear idea of the one who such cardinal. It is a reality from other culture.

The names «Морелия», “Черновар» are neologisms, and also don't promote creation of visions. In view of an internal form of a word, respondents react to a word by means of associations: the name "Морелия» causes the images connected with death (beautiful girl bringing death, Grim Reaper) or with the sea (angry mermaid, sea cabbage, fish, packing of crabsticks); the name «Черновар» - with black color (glass with black liquid; man in black, cooking something suspicious; darkness, black viscous substance). 
The names «Паго», «Фазер», «Ходзитя» have led to the highest percent of refusals. All respondents note foreign character of these words ( «Паго»Mexican macho, Frenchman in a beret and with an easel; «Фазер»-gun at the German in a hand; "Ходзитя»-Arab woman, Belarusian, Chinese, traditional Japanese lodge, extraordinary east dish, Japanese food), but they don't cause visions.

The results received when using a method of identification of visions demonstrate that the most preferable are names forming a concrete visual or sensual image. Using as commercial names of abstract nouns ( Удача» (vodka), «Грех кардинала» (vodka)) and also semantic unfamiliar to audience words - neologisms («Морелия» (candies), «Паго» (juice), «Черновар» (beer)) and loanwords («Фазер» (candies), «Ходзитя» (wine)), it is possible to consider not quite justified.

\subsection{Method of detection of subjective preferences}

The method of detection of subjective preferences helps to define goods with the most preferable name.

During realization of this technique by the examinee the list of names given above and a question was offered: "With what name you would like to buy goods?". Examinees could note any number of names from the offered list.

The high rate of mentions (more than 30\%) has been noted at names: «Aнастасия», "Гладиатор», «Гостинчик», «Грех кардинала», «Морелия», «Наливай-ка», «Привет», «Розовый зайчик», «Самоивет», «Ярило».

Comparing these researches with results of an experiment in which individual definitions were studied, it is found out that misunderstanding of a word meaning or inaccuracy of understanding doesn't prevent to estimate this word as preferable when determining subjective preferences at all (for example, «Морелия»). This phenomenon has been noted in work of T. A. Soboleva and A. V. Superanskaya. They wrote, that creating trademarks care not so for that it was clear, and about that it had effect $[5$, p. 56].

Rather curious are names «36 копеек», «Бельй пакет», «Лампочка». Having accurately expressed meaning understood by native speakers they at the same time don't get to category of preferable.

Thus, there is no direct correlation between the concepts «preferable name» and degree of understanding of meaning of the lexical unit used as the name. 


\subsection{Method of the phonosemantic analysis}

The method of the phonosemantic analysis allows to reveal the name with the brightest positive phonetic meaning.

Each sound of the human speech has a certain subconscious meaning. For the first time by means of poll of large audience American Charles Osgood began to establish these meanings. For Russian these meanings were defined in due time by the Soviet scientist, the Doctor of Philology A. P. Zhuravlev. In his work the phonosemantic meaning of each sound of the Russian speech has been established [6]. Each word consists of a complex of sounds, and it is natural that for assessment of impact on the man of his word as sound complex it is necessary to define the general phonosemantic znachekny the sounds making this word.

A. P. Zhuravlev has defined qualitative characteristics of each sound of the Russian speech namely what he is on scales by poll of many thousands audience:

good - bad; beautiful - repellent; joyful - sad; light - dark; easy heavy; safe - terrible; kind - angry; simple - difficult; smooth-rough; roundish - angular; big - small; rough - gentle; courageous - womanly; strong - weak; cold - hot; majestic - low; loud - silent; mighty sickly; bright - dim; long - short; brave - coward; fast-slow; activepassive [6].

Thanks to the phonosemantic analysis the associations caused by sounding or tracing of the words making the name are defined. Linguistic selection of a name consists in finding of that successful subconscious image which is set not only by direct sense of a word, but also phonetics of separate sounds of this word, his emotional background.

In the phonosemantic analysis of names used the computer program allowing to analyse sound structure of a word or a phrase with the subsequent psycholinguistic interpretation of results.

The phonosemantic analysis of the nominations has yielded the following results. The bright phonetic meaning is revealed only at $35 \%$ of names of goods («36 копеек» (milk), «Анастасия» (wine), «Морелия» (candies), «Паго» (juice), «Привет» (juice), «Фазер» (candies), «Ярило» (kvass)). These words can be divided into units with positive, negative and ambiguous phonetic meaning.

«Анастасия» (wine), «Морелия» (candies), «Ярило» (kvass) have been carried to number of units with positive phonetic meaning. 
«36 копеек» (milk), «Паго» (juice), «Привет» (juice), «Фазер» (candies) have got into group of words with negative phonetic meaning.

Ambiguous names (that have gained identical quantity of the positive and negative characteristics) during the phonosemantic analysis aren't revealed. All other names have less than three bright characteristics and can be carried to words with weak phonetic meaning.

\subsection{Method of determination of esthetic appeal of a word}

The method of determination of esthetic appeal of a word allows to reveal the most attractive name from the point of view of the consumer.

During application of this technique by the examinee it is offered to answer a question: «What words from the list given below seem to you pleasant, attractive?».

At the same time, information that these words are names of drinks and confectionery is not told to examinees. Examinees can note any number of names from the offered list.

Thus, it turns out that from the point of view of examinees the most esthetically attractive is the word «Самоивет» (more than $70 \%$ of mentions).

Often as attractive words and phrases are called: «Госпожа Удача», «Гостинчик», «Морелия» (60\%), «Анастасия» (more 50\%), «Розовый зайчик», «Ярило» (46\%).

Names are seldom mentioned «Кузьмич», «Родник королевьлягушки», «Ходзитя» (less 13\%), «36 копеек», «Черновар» (about 6\%). Never has been noted the name «Бельй пакет».

It is interesting to compare data of the given research with results of the previous experiments. The accurate correlation of results with results of application of a method of subjective preferences and also with data of the phonosemantic analysis comes to light in relation to names "Анастасия», «Морелия» and «Ярило».

\section{Results of a parametrical analysis}

We will submit the summary table of results of application of a parametrical technique of the analysis of the name of goods (tab. 1).

In the table the analyzed names and the used methods are located; in places of crossing the sign "+" has noted result of application of the corresponding techniques. For example, the name «Гостинчик» causes adequate 


\section{Syniavska Olga}

definitions (more than $30 \%)(+)$, the expectations connected with the offered goods (more than 30\%) $(+)$ and also bright visions (more than $30 \%)(+)$ and so forth. In other columns of the table the crossed out section was put.

Table 1

\begin{tabular}{|c|c|c|c|c|c|c|}
\hline $\begin{array}{c}\text { methods / } \\
\text { names }\end{array}$ & 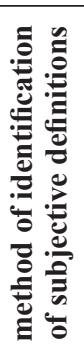 & 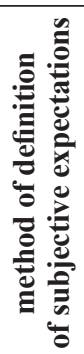 & 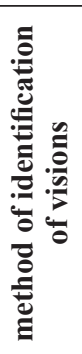 & 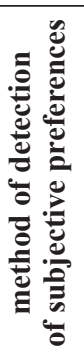 & 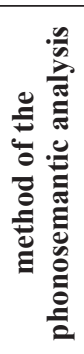 & 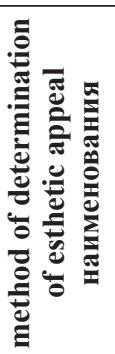 \\
\hline 36 копеек & + & - & + & + & - & - \\
\hline Анастасия & + & - & + & - & + & + \\
\hline Белый пакет & + & - & + & - & + & - \\
\hline Гладиатор & + & - & + & + & + & + \\
\hline Госпожа Удача & + & - & + & - & - & + \\
\hline Гостинчик & + & + & + & + & - & + \\
\hline Грех кардинала & - & - & - & + & - & + \\
\hline Кузьмич & + & + & + & - & - & - \\
\hline Лампочка & + & - & + & - & + & - \\
\hline Морелия & - & - & - & + & + & + \\
\hline Наливай-ка & + & + & + & + & + & + \\
\hline Паго & - & - & - & - & - & + \\
\hline Привет & - & - & - & + & - & - \\
\hline $\begin{array}{l}\text { Родник королевы- } \\
\text { лягушки }\end{array}$ & - & - & - & - & - & - \\
\hline Розовый зайчик & + & - & - & + & - & + \\
\hline Самоцвет & + & - & - & + & - & + \\
\hline Фазер & - & - & - & - & - & - \\
\hline Ходзитя & - & - & - & - & - & - \\
\hline Черновар & - & - & - & - & - & - \\
\hline Ярило & + & + & - & + & + & + \\
\hline
\end{tabular}

From the summary table it is visible that among preferable names of drinks and confectionery by results of the majority of experiments appear «Анастасия», «Гладиатор», «Гостинчик», «Наливай-ка», «Ярило». 
Among the least preferable commercial names have appeared «Гpex кардинала», «Паго», «Привет», «Родник королевы-лягуики», «Самоияет», «Фазер», «Ходзитя», «Черновар».

The qualitative and quantitative analysis of results of experiments demonstrates that names " 36 копеек», «Бельіи пакет», "Госпожа Удача», «Кузьмич», «Лампочка», «Морелия», «Розовый зайчик», «Самоияет» are contradictory from the point of view of use as the name of drinks and confectionery.

Comparing results of this experiment with the linguistic criteria described earlier it is possible to note the following.

Names which were estimated as successful from the point of view of linguistic parameters were positive and by results of an experiment: «Анастасия» (wine), «Гладиатор» (beer), «Гостинчик» (candies), «Наливай-ка» (vodka), «Ярило» (kvass).

Concerns also names which have been noted as negative: «Гpex кардинала» (vodka), «Паго» (juice), «Привет» (juice), «Родник королевы-лягушки» (wine), «Самоцвет» (tea), «Фазер» (candies), «Ходзитя» (wine), «Черновар» (beer).

Names which in practice were neutral («36 копеек» (milk), «Бельій пакет» (juice), «Госпожа Удача» (vodka), «Кузьмич» (vodka), «Лампочка» (vodka), «Морелия» (candies), «Розовый зайчик» (cocktail), by means of the linguistic analysis have been distributed on successful («Госпожа Удача» (vodka), «Кузьмич» (vodka), «Розовыій зайчик» (cocktail), «Самоивет» (tea)) and unsuccessful («36 копеек» (milk), «Бельй пакет» (juice), «Лампочка» (vodka), «Морелия» (candies)) as a description of goods.

Thus, by means of the parametrical analysis it was succeeded to prove adequacy of the offered linguistic criteria of the ideal name on practical material.

\section{Conclusion}

The quality of set of the interconnected criteria of an adequate name and its efficiency can be revealed by means of the parametrical analysis.

The parametrical analysis of the name is the method of a research assuming the description of the commercial nomination in a number of previously selected parameters.

The parametrical analysis assumes use of the following techniques: method of subjective definitions, method of definition of subjective expec- 
tations, method of identification of visions, method of definition of subjective preferences, method of the phonosemantic analysis, method of determination of esthetic appeal.

The purpose of the parametrical analysis - experimentally to confirm adequacy of theoretical criteria of the ideal name in practice.

As examinees 60 people aged from 15 up to 55 years have been chosen. Survey was conducted in an individual form. Informants were offered to answer a number of previously prepared questions by means of which names were estimated from the point of view of their compliance to criteria of the ideal name.

Results of the parametrical analysis of the commercial nomination are illustrated on the example of group of previously selected names of drinks and confectionery. They are the following: «36 копеек» (milk), «Анастасия» (wine), «Бельй пакет» (juice), «Гладиатор» (beer), «Госпожа Удача» (vodka), «Гостинчик» (candies), «Грех кардинала» (vodka), «Кузьмич» (vodka), «Лампочка» (vodka), «Морелия» (candies), «Наливай-ка» (vodka), «Паго» (juice), «Привет» (juice), «Родник королевь-лягушки» (wine), «Розовый зайчик» (cocktail), “Самоцвет» (tea), "Фазер» (candies), «Ходзитя» (wine), «Черновар» (beer), «Ярило» (kvass).

The linguistic analysis of these names of confectionery and drinks from the point of view of their compliance to criteria of the ideal name has brought the following results.

Successful should be considered such names as «Анастасия», «Гладиатор", "Госпожа Удача», "Гостинчик», "Кузьмич», "Наливайко», «Розовый зайчик», «Самоивет», «Ярило». They correspond to a number of criteria which have been put forward as defining for the ideal name.

Names «36 копеек», «Бельй пакет», «Грех кардинала», «Лампочка», «Морелия», «Паго», «Привет», «Родник королевы-лягушки», «Фазер», «Ходзитя», «Черновар» are estimated as negative as aren't suitable as a neym on a number of characteristics.

The parametrical analysis of names of drinks and confectionery has brought the following results.

By means of a method of definition of subjective definitions it was practically succeeded to establish that the names "Грех кардинала», «Морелия», «Паго», «Родник королевь-лягушки», «Фазер», «Ходзитя», «Черновар» are unsuccessful as examinees had problems with their definition. It is connected with the fact that some of these words, breaking pho- 
netic criterion, are insufficiently harmonious and are hard said («Паго», «Ходзитя»). Other names don't conform to the lexical requirement - it is neologisms («Морелия», «Паго», «Черновар») and loanwords («Фазер», «Ходзитя»). These words aren't adapted to a daily lexicon of consumers and are badly perceived by them. The names «Грех кардинала», «Родник королевь-лягушки» are unsuccessful as names of goods as they have negative figurativeness and cause negative associations.

Results of the experiment made by means of a method of definition of subjective expectations confirm a thought that use as commercial names of the words semantic unfamiliar to the native speaker, hardly is justified, for example, most of examinees consider that under the name «Морелия» seafood is on sale, «Фазер»- household appliances, and «Ходзитя»-sushi.

Analyzing the results received when using a method of identification of visions it is possible to claim that the most preferable are names forming a concrete visual or sensual image. Use as commercial names of abstract nouns and also the words semantic unfamiliar to audience (neologisms, loanwords), it is possible to consider not quite justified.

Comparing these researches it is found out that misunderstanding of a word meaning or inaccuracy of understanding doesn't prevent to estimate this word as preferable when determining subjective preferences at all (for example, «Морелия»).

Names «36 копеек», «Бельий пакет», «Лампочка» have accurate meaning which native speakers understand, but they don't get to category of preferable. Thus, there is no direct correlation between the concepts «preferable name» and degree of understanding of meaning of the lexical unit used as the name.

Following the results of the phonosemantic analysis, it is possible to draw the following conclusions. The bright phonetic meaning is revealed only at 35\% of names of goods: «36 копеек», «Анастасия», «Морелия», «Паго», «Привет», «Фазер» «Ярило».

All other names have typed less than three bright characteristics and can be carried to words with weak phonetic meaning.

Words with bright phonetic meaning can be divided into units with positive, negative and ambiguous phonetic meaning. "Анастасия», «Морелия», "Ярило» have been carried to number of units with positive phonetic meaning. With negative phonetic meaning «36 копеек», "Паго», «Привет», «Фазер» have got into group of words. Ambiguous (that is the 
positive and negative characteristics which have gained identical quantity) names during the phonosemantic analysis aren't revealed.

By results of a method of determination of esthetic appeal, it turns out that from the point of view of examinees the most esthetically attractive is the word «Самоивет» (more than 70\% of mentions).

Often as attractive the names «Госпожа Удача», «Гостинчик», «Морелия» (60\%), «Анастасия» (more than 50\%), «Розовый зайчик», «Ярило» (46\%) are called. The names «Кузьмич», «Родник королевы-лягушки», «Ходзитя» (less than 13\% of mentions), «36 копеек», «Черновар» (about 6\%) are seldom mentioned. Never has been noted the name «Бельй пакет».

By comparison of these all experiments the accurate correlation of results with results of application of a method of subjective preferences and also with data of the phonosemantic analysis comes to light in relation to the names «Анастасия», «Морелия» and «Ярило».

By means of the made experiment the attempt to prove adequacy of the offered linguistic criteria of the ideal name by means of the parametrical analysis has been made.

Prospects of a further research are studying of commercial names within communicative and functional approach from positions of cognitive linguistics as segment of onomastic space and fragment of the Russian language picture of the world and also studying of features of the commercial nominations of other objects.

\section{References:}

1. Novichikhina M. E. (2007) Kak vy firmu nazovete... [How you will call the firm]. Moscow: Vostok-Zapad (in Russian)

2. Sedaeva O. V. (1998) Neeffektivnye kommercheskie nazvaniya [Inefficient commercial names]. Proceedings of 5th regional scientific and methodical conference Culture of communication and her formation, Voronezh: Poligraf, pp. 23-25.

3. Slukhay N. V. (2009) Lingvisticheskie aspekty neyminga [Linguistic aspects of a naming]. Philological sciences: synchronic and diachronic aspects. pp. 397-405.

4. Slukhay N. V. (2010) Psikhosemantika neyma (na materiale russkoyazychnykh imen kommercheskoy sfery) [Psychosemantics of a brand name (on material of Russian names of the commercial sphere)]. Language and conceptual pictures of the world, vol. 29, pp. 278-284.

5. Soboleva T.A., Superanskaya A.V. (1986). Tovarnye znaki [Trademarks]. Moscow: Nauka. (in Russian)

6. Zhuravlev A. P. Foneticheskoe znachenie [Phonetic meaning]. Leningrad: Leningrad. gos. un-t. (in Russian) 